\title{
Surface antigen profiles of leukocytes and melanoma cells in lymph node metastases are associated with survival in AJCC stage III melanoma patients
}

\author{
Kimberley L. Kaufman • Swetlana Mactier • Nicola J. Armstrong • \\ Duthika Mallawaaratchy • Scott N. Byrne • Lauren E. Haydu • Valerie Jakrot • \\ John F. Thompson • Graham J. Mann • Richard A. Scolyer • Richard I. Christopherson
}

Received: 3 July 2013/Accepted: 9 January 2014 / Published online: 17 January 2014

(c) The Author(s) 2014. This article is published with open access at Springerlink.com

\begin{abstract}
There is an urgent need to identify more accurate prognostic biomarkers in melanoma patients, particularly in those with metastatic disease. This study aimed to identify melanoma and leukocyte surface antigens predictive of survival in a prospective series of AJCC stage $\mathrm{IIIb} / \mathrm{c}$ melanoma patients $(n=29)$. Live cell suspensions were prepared from melanoma metastases within lymph nodes (LN). The suspensions were immuno-magnetically separated into $\mathrm{CD}_{4} 5^{+}$(leukocyte) and $\mathrm{CD}^{-} 5^{-}$(nonhematopoietic, enriched melanoma cell) fractions. Surface antigens on $\mathrm{CD}_{4} 5^{-}$and $\mathrm{CD} 45^{+}$cell populations were profiled using DotScan ${ }^{\mathrm{TM}}$ microarrays (Medsaic Pty. Ltd.) and showed differential abundance levels for 52 and 78 antigens respectively. Associations of the surface profiles
\end{abstract}

Electronic supplementary material The online version of this article (doi:10.1007/s10585-014-9636-7) contains supplementary material, which is available to authorized users.

K. L. Kaufman $(\bowtie) \cdot$ S. Mactier · D. Mallawaaratchy ·

R. I. Christopherson

School of Molecular Bioscience, University of Sydney, Sydney, NSW 2006, Australia

e-mail: kim.kaufman@sydney.edu.au

\section{N. J. Armstrong}

Garvan Institute of Medical Research, Darlinghurst, NSW 2010 , Australia

N. J. Armstrong

School of Mathematics and Statistics and Prince of Wales Clinical School, University of New South Wales, Kensington, NSW 2052, Australia

S. N. Byrne

Discipline of Infectious Diseases and Immunology Sydney

Medical School, University of Sydney, Sydney, NSW 2006,

Australia with clinicopathologic and outcome data (median followup 35.4 months post LN resection) were sought using univariate (log-rank test) and multivariate (Wald's test; modelled with patient's age, gender and AJCC staging at LN recurrence) survival models. CD9 $(p=0.036)$, CD39 $(p=0.004)$ and $\operatorname{CD} 55(p=0.005)$ on $\mathrm{CD}^{+} 5^{+}$leukocytes were independently associated with distant metastasis-free survival using multivariate analysis. Leukocytes with high CD39 levels were also significantly associated with increased overall survival (OS) in multivariate analysis $(p=0.016)$. LNs containing leukocytes expressing CD11b $(p=0.025), \mathrm{CD} 49 \mathrm{~d}(p=0.043)$ and CD79b $(p=0.044)$ were associated with reduced OS on univariate analysis. For enriched melanoma cells (CD45 ${ }^{-}$cell populations), 11 surface antigens were significantly correlated with the disease-free interval (DFI) between diagnosis of culprit primary melanoma and $\mathrm{LN}$ metastasis resection. Nine antigens on $\mathrm{CD}_{4} 5^{+}$leukocytes also correlated with DFI.

\section{S. N. Byrne}

Discipline of Dermatology, Bosch Institute, Faculty of Medicine, Sydney Medical School, Sydney, NSW 2006, Australia

L. E. Haydu · V. Jakrot · J. F. Thompson ·

G. J. Mann · R. A. Scolyer

Melanoma Institute Australia, North Sydney, NSW 2060, Australia

L. E. Haydu

Discipline of Surgery, Sydney Medical School, The University of Sydney, Sydney, NSW 2006, Australia

\section{G. J. Mann}

Westmead Institute of Cancer Research, The University of Sydney at Westmead Millennium Institute, Westmead, NSW 2145, Australia 
Following validation in independent datasets, surface markers identified here should enable more accurate determination of prognosis in stage III melanoma patients and provide better risk stratification of patients entering clinical trials.

Keywords Antibody microarray $\cdot$ Metastatic melanoma CD antigen $\cdot$ Survival $\cdot$ Prognosis

$\begin{array}{ll}\text { Abbreviations: } \\ \text { AJCC } & \text { American Joint Committee on Cancer } \\ \text { DFI } & \text { disease-free interval } \\ \text { DMFS } & \text { distant metastasis-free survival } \\ \text { ECM } & \text { extracellular matrix } \\ \text { HR } & \text { hazard ratio } \\ \text { LN } & \text { lymph node } \\ \text { MIA } & \text { Melanoma Institute Australia } \\ \text { MDSC } & \text { myeloid-derived suppressor cell } \\ \text { NK } & \text { natural killer } \\ \text { OS } & \text { overall survival } \\ \text { TGF- } \beta 1 & \text { transforming growth factor- } \beta 1\end{array}$

\section{Introduction}

Melanoma is a major cause of morbidity and mortality in many Western countries and its incidence is increasing [1]. In these populations, melanoma is one of the most common cancers amongst young adults and is a major public health problem [2,3]. Compared with other cancers, melanoma has a propensity for metastasis early in disease progression, even from thin (early stage) primary tumors [4]. Nevertheless, when detected and treated early, melanoma has a high cure rate. Mortality in melanoma is usually a consequence of metastatic spread. A detailed melanoma staging system was developed by the American Joint Committee on Cancer (AJCC) to stratify patients into prognostic groups, taking into account the principal prognostic factors including primary tumor characteristics (such as tumor thickness, ulceration, mitotic rate) and the presence, number and size of loco-regional and distant metastases [5]. However, outcomes for patients within individual AJCC stage sub-categories can be vastly different, particularly for those with metastatic

\section{R. A. Scolyer}

Department of Tissue Pathology and Diagnostic Oncology,

Royal Prince Alfred Hospital, Camperdown, NSW 2050,

Australia

\section{R. A. Scolyer}

Discipline of Pathology, Sydney Medical School, The University

of Sydney, Sydney, NSW 2006, Australia disease. For example, $50 \%$ of patients who present with clinically palpable regional lymph node (LN) metastases (AJCC stage IIIc disease) will be dead within 2 years. However, $50 \%$ of those who are still alive at 2 years will live for more than 20 years. Identification of parameters and biomarkers that can collectively predict prognosis for AJCC stage III patients would facilitate more accurate risk stratification, rational selection of patients who may benefit from adjuvant therapies, and development of screening and follow up protocols.

Many studies have sought to identify protein biomarkers, including surface antigens that can be utilized for prognosis of primary melanoma [6, 7]. Whilst some biomarkers correlate with melanoma progression and survival, few have shown significance independent of other well known and more easily measured prognostic parameters (such as tumor thickness) and even less have been validated in independent datasets [820]. An extensive immuno-phenotype (surface profile) using antibody microarrays may identify disease signatures able to predict the clinical behavior of melanoma (e.g., likely sites of metastatic spread) and patient outcome. Most antibody microarrays detect soluble proteins. By contrast, DotScan ${ }^{\mathrm{TM}}$ (Medsaic Pty. Ltd., Sydney, Australia) captures live cells that express the corresponding antigens on their surface. The data obtained correlate well with antigen levels determined by flow cytometry [21-23]. DotScan ${ }^{\mathrm{TM}}$ has been applied to a variety of clinical samples, including leukaemia, lymphoma, peripheral blood leukocytes from HIV and heart transplant recipients, and colorectal cancer specimens [23-29]. Antibodies printed on the microarray used in the current study were selected based on their association with melanoma disease progression and/or prognosis. Some of these surface molecules are important targets for anti-melanoma drugs, although their functions have not been fully elucidated.

In the present study, we have used an extended DotScan ${ }^{\mathrm{TM}}$ microarray [25] to detect surface antigen profiles of live melanoma cells and leukocytes from fresh surgically excised metastatic melanoma LN tumors (AJCC stage IIIb/c disease) and interrogated the findings with prospectively collected clinical and follow up data from each patient. We identified a number of differentially abundant antigens associated with distant metastasis-free and overall survival (OS). In addition, we have identified antigens associated with a prolonged disease-free interval between initial primary melanoma diagnosis and resection of nodal metastatic disease.

\section{Experimental procedures}

Melanoma lymph node metastases

Melanoma LN metastases $(n=38)$ were obtained from the Melanoma Institute Australia (MIA) Bio-specimen Bank 
with written informed patient consent and IRB approval (Sydney South West Area Health Service institutional ethics review committee (RPAH Zone) Protocol Nos., X06-0140，X08-0155/HREC 08/RPAH/262，X11-0023/ HREC 11/RPAH/32 and X07-0202/HREC/07/RPAH/30). Fresh tumor samples were examined by a specialist melanoma pathologist (RAS) and carefully macro-dissected from non-tumor tissues avoiding necrotic areas and normal lymph node tissue. A high-percentage melanoma tumor content $(>80 \%)$ and low necrosis $(<20 \%)$ were verified by examining hematoxylin and eosin-stained sections and immunohistochemistry for melanoma antigens S-100 protein, HMB45 and MelanA/MART-1.

The fresh metastatic melanoma LN tumors were collected prospectively over a 13-month period from February 2009 and subsequent clinical follow-up data spaning 24.3-43.1 months (median 35.4 months) post $\mathrm{LN}$ resection was obtained. Nine patients were excluded from the study due to a high level of necrosis and poor cell viability $(n=3)$, a non-melanoma diagnosis following subsequent histopathology $(n=3)$ or evidence of distant metastases at diagnosis of the culprit primary melanoma ( $n=3$; stage IV at initial diagnosis). The remaining 29 cases were analyzed for demographic, primary tumor and metastasis pathologic and survival data as detailed in Table 1. As of May 2013, 13 patients were alive [11 with no sign of recurrence (NSR) and 2 with melanoma], 15 patients had died of melanoma and 1 patient had died of unrelated causes. One patient had synchronous AJCC stage IV disease at the time of $\mathrm{LN}$ recurrence and was excluded from the survival analyses. Patients with occult primary disease or with previous $\mathrm{LN}$ involvement were excluded from the DFI correlation analysis. Despite good cell viability, two patient samples had poor binding of cells to the microarray and were used for Western blot analysis.

In summary, we investigated the associations of $\mathrm{CD}^{-} 5^{-}$ enriched melanoma cell $(n=25)$ and $\mathrm{CD}^{+} 5^{+}$leukocyte $(n=23)$ immuno-profiles in melanoma patients with distant metastasis-free survival (DMFS) and OS post LN resection of stage $\mathrm{IIIb} / \mathrm{c}$ disease. Immuno-profiles of CD45 ${ }^{-}$enriched melanoma cells $(n=20)$ and CD $45^{+}$ leukocytes $(n=19)$ were also correlated with DFI (time between diagnosis of culprit primary melanoma and LN resection; see Supplementary Table 1).

Preparation of viable, single cell suspensions

Fresh tumor samples were placed in Hanks' balanced salt solution (HBSS; Sigma-Aldrich, St. Louis. MO, USA) at $4{ }^{\circ} \mathrm{C}$ and processed within $16 \mathrm{~h}$ to ensure cell viability. Samples were finely diced with a scalpel blade and incubated in a dissociation buffer containing $1 \%(\mathrm{w} / \mathrm{v})$ collagenase type IV (Worthington, Lakewood, NJ, USA) and
$0.2 \%$ (w/v) DNase I (bovine pancreas; Sigma-Aldrich) in HBSS at $37^{\circ} \mathrm{C}$ for $1 \mathrm{~h}$, with gentle vortexing every $15 \mathrm{~min}$. The semi-digested tissue was then passed through a fine wire mesh strainer and the resulting suspension centrifuged $\left(450 \times g, 4{ }^{\circ} \mathrm{C}, 5 \mathrm{~min}\right)$. Small aggregates were removed using $200 \mu \mathrm{m}$ and then $50 \mu \mathrm{m}$ Filcon cup filters (BD Biosciences, San Jose, CA, USA), resulting in a single-cell suspension with 70-90\% viability, that was frozen at $-80{ }^{\circ} \mathrm{C}$ in fetal calf serum (FCS) with $10 \%$ DMSO until required.

Separation of leukocytes from melanoma cells

Prior to surface profiling, samples were thawed and pelleted $\left(400 \times g, 4{ }^{\circ} \mathrm{C}, 5 \mathrm{~min}\right)$ and the cells resuspended in RPMI growth medium with $0.2 \%(w / v)$ DNase I for $10 \mathrm{~min}$ at room temperature. Leukocytes were bound to CD45 antibody microbeads (Miltenyi Biotec, Auburn, CA, USA) and separated from cell suspensions using an Auto$\mathrm{MACS}^{\mathrm{TM}}$ Pro Separator (Miltenyi Biotec) as per the manufacturer's instructions. Briefly, $2 \times 10^{7}$ cells were incubated with $40 \mu \mathrm{L}$ anti-CD45 microbeads in a buffer containing PBS with $0.1 \%$ BSA, 2 mM EDTA and $2 \%$ $\mathrm{AB}$ serum at $4{ }^{\circ} \mathrm{C}$ for $10 \mathrm{~min}$. Cells were diluted, pelleted $\left(300 \times g, 4{ }^{\circ} \mathrm{C}, 10 \mathrm{~min}\right)$, resuspended in $500 \mu \mathrm{L}$ of the above buffer and passed through a $50 \mu \mathrm{m}$ filter before removal of magnetic beads with attached $\mathrm{CD} 45^{+}$cells using the 'deplete' setting on the AutoMACS ${ }^{\mathrm{TM}}$ Pro Separator. To confirm depletion of the $\mathrm{CD} 45^{+}$cells, a melanoma LN cell suspension was labelled with mouse monoclonal anti-CD45-PE or anti-IgG2a-PE (Miltenyi Biotec) and analyzed on a FACScalibur ${ }^{\mathrm{TM}}$ (BD Biosciences) before and after immuno-magnetic separation (Supplementary Fig 1).

\section{Capture of cells on DotScan ${ }^{\mathrm{TM}}$ microarrays}

The microarrays were constructed as duplicate dots (10 nl) on nitrocellulose-coated slides (Grace Bio-labs Inc., Bend, OR, USA) as previously described [25]. All array antibodies were specific to extracellular domain sequences where possible, if not the full-length protein. However, antibody avidity might be reduced following its immobilization to the nitrocellulose slide. $\mathrm{CD} 45^{+}$and $\mathrm{CD} 45^{-}$live cell suspensions were suspended at a density of $1.3 \times 10^{7} /$ $\mathrm{ml}$ in growth medium (RPMI with $10 \% \mathrm{FCS}$ and $2 \%$ heat-inactivated human $\mathrm{AB}$ serum) and incubated on premoistened microarrays in a humidified chamber at $37{ }^{\circ} \mathrm{C}$ for $30 \mathrm{~min}$. Captured cells were fixed in $3.7 \%$ formaldehyde for $30 \mathrm{~min}$ at room temperature and washed in PBS. Arrays were imaged directly with an optical scanner (Medsaic Pty Ltd) without staining or labelling, and analyzed using DotScan ${ }^{\mathrm{TM}}$ software (Medsaic Pty Ltd) [23]. 


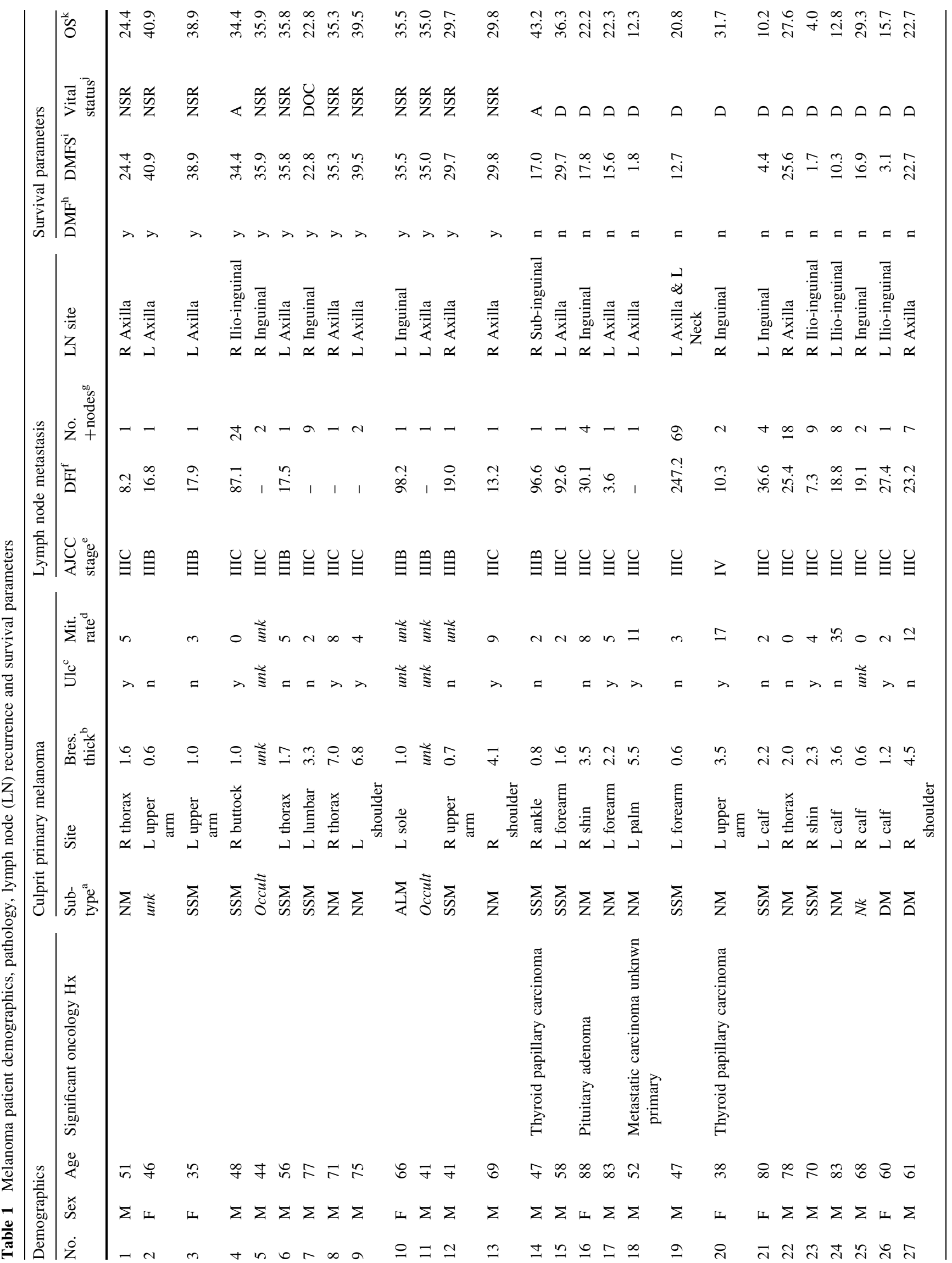


This software quantifies the density of cell binding on each antibody dot above background levels, on an 8-bit scale from 1-256. Dot intensities on an array reflect the proportion of cells expressing each antigen and/or the level of expression of a particular antigen per cell. The average numbers of cells bound to each dot, determined microscopically, correlate well with average binding density values. The number of cells captured on an antibody dot in the microarray also depends on the affinity of the antibodyantigen interaction.

Statistical analysis of antibody microarray results

Cell binding densities were corrected for background and isotype-control binding and the duplicate array information was averaged and $\log _{2}$-transformed. Microarray data, consisting of 52 antigens for melanoma $\left(\mathrm{CD} 45^{-}\right)$samples and 78 antigens for leukocytes $\left(\mathrm{CD} 45^{+}\right)$, were median normalized separately. DMFS was calculated from the time of LN resection to appearance of distant metastasis or last clinical follow-up. OS was calculated from the time of $\mathrm{LN}$ resection, to last clinical follow-up or death. Univariate (log-rank test) and multivariate (Wald's test) survival models were used to assess associations between antigen levels and patient survival (DMFS and OS). Due to the small patient numbers (enriched melanoma cells, $n=25$ and leukocytes, $n=23$ ), we were unable to include all clinical variables in a single survival model. Instead, we restricted our attention to the patient's age, gender and AJCC stage at LN resection (stage IIIb or IIIc) because these are the strongest known predictors of outcome in AJCC stage III melanoma patients. For patients with multiple primary melanomas $(n=3)$, the culprit primary was designated on the basis of the presence of the most adverse prognostic factors and its anatomic site, due to a greater likelihood that it was the source of the metastatic disease, as previously described [30, 31]. We censored patients who died of other causes, and for the DMFS analysis, patients who had no distant metastasis. For the DFI correlation analysis, Pearson's $r^{2}$ values were calculated to determine the relationship between surface antigen levels and the time (in months) between the culprit primary melanoma diagnosis and $\mathrm{LN}$ resection of stage III metastatic disease.

\section{Western blotting}

Total protein extracts were made from $\mathrm{CD} 45^{+}$cell populations from $13 \mathrm{LN}$ samples (see Supplementary Table 1) by lysing cells in a denaturing urea buffer containing $7 \mathrm{M}$ urea, $2 \mathrm{M}$ thiourea, $40 \mathrm{mM}$ Tris, $65 \mathrm{mM}$ DTT supplemented with $0.1 \mathrm{mM}$ phenylmethylsulfonyl fluoride (PMSF) and centrifuged $\left(16,000 \times g, 15 \mathrm{~min}, 4{ }^{\circ} \mathrm{C}\right)$. Due to 
A

\begin{tabular}{|c|c|c|c|c|c|c|}
\hline TCR $\alpha / \beta$ & TCR $y / \delta$ & $1 a$ & 2 & 3 & 4 & 5 \\
\hline 7 & 8 & 9 & 10 ALB2 & $11 a$ & $11 \mathrm{~b}$ & $11 \mathrm{c}$ \\
\hline 13 & 14 & 15 & 16 & 19 & 20 & 21 \\
\hline 22 & 23 & 24 & 25 & 28 & 29 & 31 \\
\hline 32 & $\begin{array}{c}33 \\
\text { WM53 }\end{array}$ & $\begin{array}{c}34 \\
\text { OBEND }\end{array}$ & 36 & 37 & 38 & 40 \\
\hline 41 & $42 a$ & 43 & 44 & 45 & $45 \mathrm{RA}$ & $45 \mathrm{RO}$ \\
\hline $49 d$ & $49 e$ & 52 & 54 & 56 & $\begin{array}{l}57 \\
\text { PH }\end{array}$ & 60 \\
\hline 61 & $62 \mathrm{~L}$ & $62 \mathrm{E}$ & $62 \mathrm{P}$ & 64 & 69 & $66 c$ \\
\hline 71 & 77 & $79 a$ & $79 b$ & 80 & 86 & 88 \\
\hline 95 & 102 & 103 & 117 & $120 \mathrm{a}$ & 122 & 126 \\
\hline 128 & 130 & 134 & 135 & 138 & 154 & $235 a$ \\
\hline HLA-DR & FMC7 & K & $\lambda$ & slg & Mab & \\
\hline & & & & & & \\
\hline 39 & $49 b$ & $49 c$ & $49 f$ & 51 & 55 & 58 \\
\hline 59 & 63 MEM25 & $\begin{array}{c}63 \\
460305\end{array}$ & $66 a$ & 73 & 81 & $107 a$ \\
\hline 144 & 146 & 147 & 151 & 166 & 171 & 181 \\
\hline 182 & 183 & 184 & 200 & 228 & 252 & 261 \\
\hline 262 & 263 & 264 & 265 & 271 & 324 & 325 \\
\hline 331 & 334 & EphA2 & erbB3 & Gp100 & VEGF3 & Osteo \\
\hline Ezrin & Claudin & cMet & Par1 & MAGE1 & AMFR & HSP90 \\
\hline \multicolumn{7}{|l|}{ NG2 } \\
\hline & & & & & & \\
\hline $\begin{array}{l}\text { IgG1 } \\
500\end{array}$ & $\begin{array}{l}\text { IgG1 } \\
200\end{array}$ & $\begin{array}{r}\text { IgG1 } \\
50\end{array}$ & $\frac{\lg _{500} 2 a}{}$ & $\lg _{200}$ & $\lg _{50}$ & $\lg _{500} 2 b$ \\
\hline $\operatorname{lgg}_{200} \mathrm{~b}$ & $\lg _{100}$ & $\begin{array}{l}\operatorname{lgM} \\
500\end{array}$ & $\frac{\lg M}{200}$ & $\lg _{50}$ & & \\
\hline
\end{tabular}

B

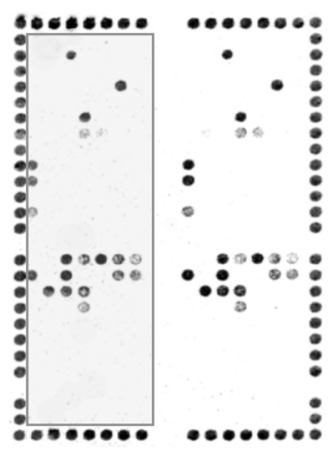

E
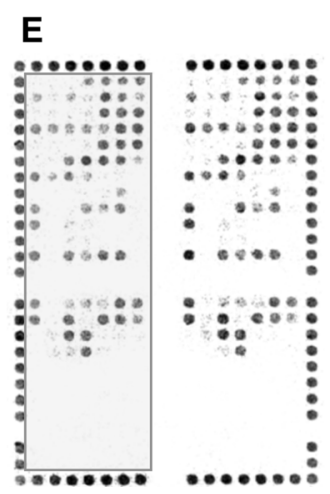

Fig. 1 Immuno-phenotypes of cell suspensions isolated from lymph node tumors resected from stage III metastatic melanoma patients. a Antibody key for the microarray, printed in duplicate on nitrocellulose slides. Antibody key is zone framed in grey on $(\mathbf{b}-\mathbf{g})$. (bd) Antibody binding patterns of enriched melanoma cells (CD45 $\left.{ }^{-}\right)$ from patients 19, 13 and 8 respectively. (e-g) Antibody binding patterns of leukocytes attached to $\mathrm{CD} 45^{+}$magnetic beads $\left(\mathrm{CD} 45^{+}\right)$ isolated from patients 19,25 and 7 respectively. The numbers in

limited sample availability, the level of one surface antigen (CD55) was confirmed by Western blotting. Proteins were separated by $10 \%$ SDS-PAGE and transferred to a PVDF membrane at $400 \mathrm{~mA}$ for $1 \mathrm{~h}$ using a Criterion ${ }^{\mathrm{TM}}$ Blotter (BioRad, Hercules, CA, USA). The membrane was blocked in $5 \%(\mathrm{w} / \mathrm{v})$ skim milk and incubated overnight at $4{ }^{\circ} \mathrm{C}$ with a 1:5,000 dilution of rabbit monoclonal antibody against CD55 (EPR6689, Epitomics, Inc., Burlingame, CA, USA) and 1:10,000 dilution of mouse monoclonal antibody against succinate dehydrogenase subunit A (SDHA; Santa Cruz Biotechnology, Inc., Santa Cruz, CA, USA). Membranes were then incubated with donkey, anti-rabbit (Abcam, Waterloo, NSW, Australia) and goat, anti-mouse (Santa Cruz) secondary antibodies conjugated to horseradish peroxidase for $2 \mathrm{~h}$ at room temperature. Bands were visualized with ECL detection reagent and imaged using chemiluminescence film (GE Healthcare, Piscataway, NJ, USA). Bands were quantified using ImageQuantTL density analysis software (GE Healthcare). An average of the density of SDHA and the total protein stain was used as an internal loading control. To confirm the association with
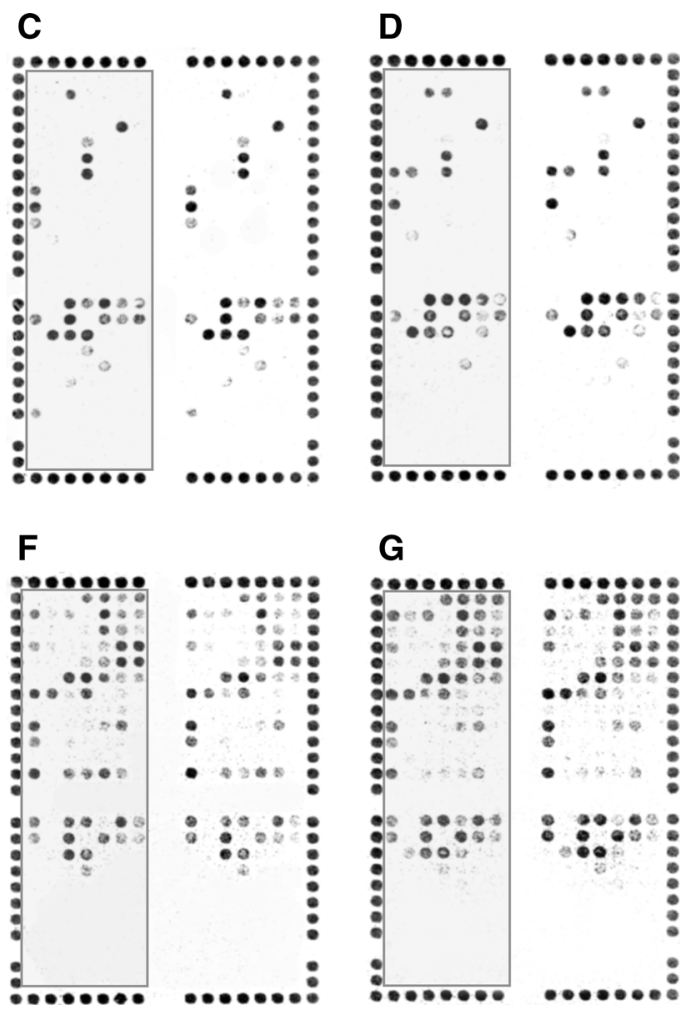

(a) refer to antibodies against corresponding $\mathrm{CD}$ antigens; IgG1, IgG2a, IgG2b, IgG3 and IgM are murine isotype control antibodies tested at the concentrations shown in $\mu \mathrm{g} / \mathrm{mL}$; TCR $\alpha / \beta$, TCR $\gamma / \delta$, HLA-DR, FMC7, $\mathrm{k}$ and $\lambda$ are antibodies against T-cell receptors $\alpha / \beta$ and $\gamma / \delta$, HLA-DR, FMC-7, kappa and lambda immunoglobulin light chains, respectively. A border of CD44/CD29 alignment dots is shown around the duplicate microarrays of $(\mathbf{b}-\mathbf{g})$

DMFS, CD55 level ratios were tested using the log-rank test described above.

\section{Results}

Surface profiles of melanoma LN metastases

Single cell suspensions of 29 metastatic melanoma LN specimens were immuno-magnetically separated to isolate $\mathrm{CD}_{4} 5^{+}$leukocytes and enrich for melanoma cells $\left(\mathrm{CD} 45^{-}\right)$. Cell separation was confirmed by flow cytometry (Supplementary Fig. 1). This together with a failure of the CD45 ${ }^{-}$cells to bind CD45, CD45RA and CD45RO or other leukocyte specific antigens on the arrays confirmed the effectiveness of the cell separation. Adequate cell numbers $\left(4 \times 10^{6}\right.$ cells $)$, viability $(>70 \%)$ and binding were achieved for $\mathrm{CD}_{4} 5^{-}$and $\mathrm{CD} 45^{+}$cell populations from 26 to 24 patient samples, respectively (See Fig. 1 for optical scan of cell binding patterns). Cell binding to 52 and 78 antibodies was observed for $\mathrm{CD}^{-} 5^{-}$enriched 
melanoma cells and $\mathrm{CD}_{4} 5^{+}$leukocytes, respectively. Normalization and subsequent analyses were performed using this these data. Some antigens were expressed at variable levels on all $\mathrm{CD} 45^{-}$fractions, e.g., CD29, CD44, CD51, CD63, CD71, CD146 and CD151. Although the leukocyte $\left(\mathrm{CD} 45^{+}\right)$antigen profiles were more diverse, perhaps reflecting the heterogeneity of the cell populations, as expected, there was consistent binding to the antibodies for CD45, and CD45RA and/or CD45RO for all patient samples.

\section{DMFS and OS analyses}

In leukocyte $\left(\mathrm{CD} 45^{+}\right)$fractions, high levels of $\mathrm{CD} 9$ were associated with decreased DMFS on both univariate and multivariate analyses $(\mathrm{HR}=2.67, \quad p=0.039$ and $\mathrm{HR}=3.73, p=0.036$, respectively; Fig. 2). In contrast, increased levels of CD39 and CD55 were associated with increased DMFS on univariate $(\mathrm{HR}=0.29$ and 0.28 , $p=0.019$ and 0.006 , respectively) and multivariate analyses $(\mathrm{HR}=0.01$ and $0.10, p=0.004$ and 0.005 , respectively). A significant association between increased levels of CD55 and DMFS was confirmed by Western blotting (HR $=2.8 ; p=0.008$; see Fig. 4). The $\mathrm{CD} 45^{-}$enriched melanoma cells displayed differential binding to CD117 (cKIT), with higher levels associated with decreased DMFS on univariate analysis with borderline significance $(\mathrm{HR}=1.56 ; p=0.07)$.

Higher levels of CD39 on CD45 ${ }^{+}$leukocytes were also significantly associated with increased OS using both univariate and multivariate models $(\mathrm{HR}=0.29, p=0.045$ and $\mathrm{HR}=0.10, p=0.016$, respectively; Fig. 3 ). There is a documented synergy between CD39 and CD73 activities [23]. We found increased CD73 levels associated with DMFS and OS, with marginal significance $(p=0.08$ and 0.13 , respectively). When CD73 and CD39 levels were modelled together, CD39 remained significantly associated with DMFS $(p=0.027)$. Increased levels of CD11b, $\mathrm{CD} 49 \mathrm{~d}$ and $\mathrm{CD} 79 \mathrm{~b}$ on $\mathrm{CD} 45^{+}$leukocytes were associated with reduced $\mathrm{OS}(\mathrm{HR}=2.72,2.46,1.76, p=0.025$, $0.043,0.044$, respectively). However these associations were not statistically significant on multivariate analysis. Leukocyte results are summarised in Table 2 and survival plots for DMFS and OS are depicted in Figs. 2 and 3. No statistically significant association with OS was found for the 58 antigens tested on $\mathrm{CD} 45^{-}$enriched melanoma cells.

\section{DFI correlation analyses}

A proportion of patients with primary melanoma carry a risk for recurrence and distant metastases after a symptomfree period that can span decades, despite favourable prognostic determinants from their primary tumor. The relationship between this DFI, defined as the time between primary melanoma resection and resection of nodal metastases (spanning 3.6-247.2 months in this study) and antigen levels was also investigated. Enriched melanoma $\left(\mathrm{CD} 45^{-}\right)$cells showed higher levels of 11 surface antigens in resected LNs from metastatic melanoma patients with a prolonged DFI $\left(p<0.05\right.$; average $r^{2}$ of 0.484 ; see Supplementary Fig. $2 \mathrm{a}$ and Table 3). Five of these antigens are cell adhesion molecules, i.e., integrins (CD29, CD49c), tetraspanin CD63, CD56 (neural adhesion molecule, NCAM) and CD107a (lysosome-associated membrane protein 1). For $\mathrm{CD} 45^{+}$leukocyte fractions, nine antigens were correlated with shorter DFI $\left(p<0.05\right.$; average $r^{2}$ of -0.590 ; Supplementary Fig. $2 b$ and Table 3 ). Of these, eight antigens are related to $\mathrm{T}$ cell immunity, i.e., CD7, CD8, CD43, CD54, CD56, CD103, CD134 and CD166.

\section{Discussion}

Our novel methodology combines immuno-magnetic cell separation with surface antigen profiling (partial membrane proteome) to profile separated leukocyte $\left(\mathrm{CD} 45^{+}\right)$and enriched melanoma cell $\left(\mathrm{CD} 45^{-}\right)$populations. Metastatic melanoma is highly immunogenic and by profiling leukocytes separately, we can understand how melanoma cells might escape or diminish immune system control within LNs and progress to metastatic disease. Some antigens showed limited binding or were undetected across all $\mathrm{CD} 45^{+}$or $\mathrm{CD} 45-$ cell populations and were removed from the analyses. Low cell capture may be due to low antigen levels, inaccessible antigen epitopes or a reduced affinity of antibodies following immobilization on nitrocellulose. Surface antigens significantly associated with DMFS, OS and DFI are discussed below.

\section{Survival analyses}

\section{Leukocyte antigens associated with reduced survival}

Patients with shorter OS showed enhanced levels of CD79b, part of the B-cell receptor complex (BCR), implicating an elevation of B-lymphocytes in LNs resected from stage III metastatic melanoma patients with poor survival outcomes. De novo lymphatic formation or lymphangiogenesis is associated with cancer metastasis [3234]. B-lymphocyte accumulation within draining LNs is required for LN lymphatic sinus expansion in response to tumor growth and B-cell-associated lymphangiogenesis is required to increase lymph flow through the tumor-draining LNs [35]. These changes could actively promote tumor dissemination through the lymphatic system [36]. In murine models of squamous cell carcinoma, wild-type mice 

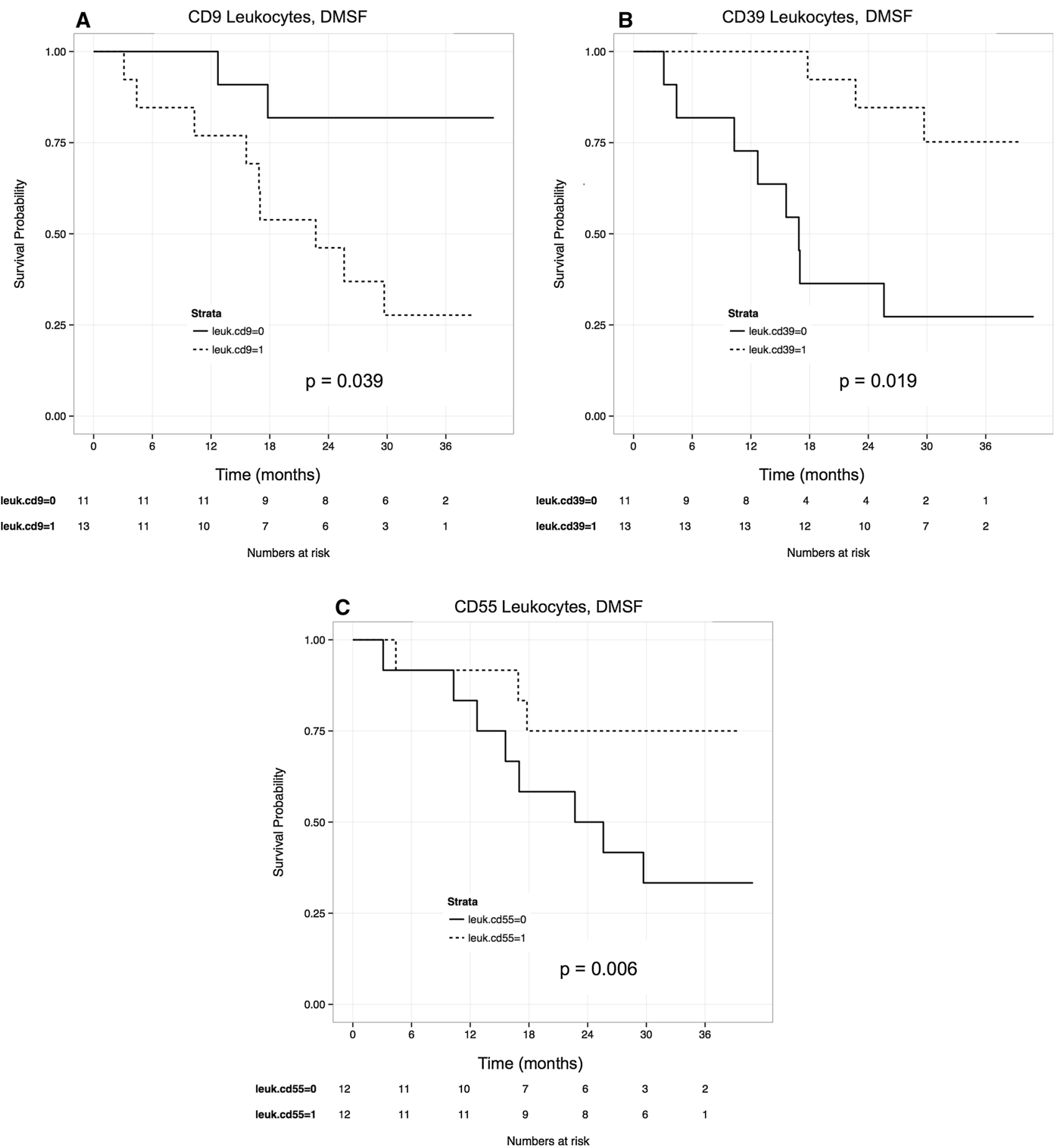

Fig. 2 Univariate cox proportional hazard models were used to evaluate associations between surface antigen levels and distant metastasis-free survival (DMFS). For graphical representation, plotted variables were dichotomized based on median antigen levels,
$0=$ low, $1=$ high. Increased levels of (a) CD9 on CD45 ${ }^{+}$leukocytes were significantly associated with with distant metastasis and poor survival outcomes. Conversely, higher levels of (b) CD39 and (c) CD55 on CD45 ${ }^{+}$leukocytes were associated with DMFS showed tumor draining LN B-cell accumulation and lymphangiogenesis and the extent of these alterations predicted progression from benign papillomas to metastatic carcinomas [37]. Primary melanomas prepare tumor-draining LNs for the seeding of metastatic disease by stimulating lymphangiogenesis and dampening sentinel node immunity prior to the arrival of malignant cells [35, 38]. A multivariate risk analysis revealed that tumor lymphangiogenesis was the most sensitive prognostic marker for melanoma sentinel LN metastasis [39]. Here, an accumulation of 
A

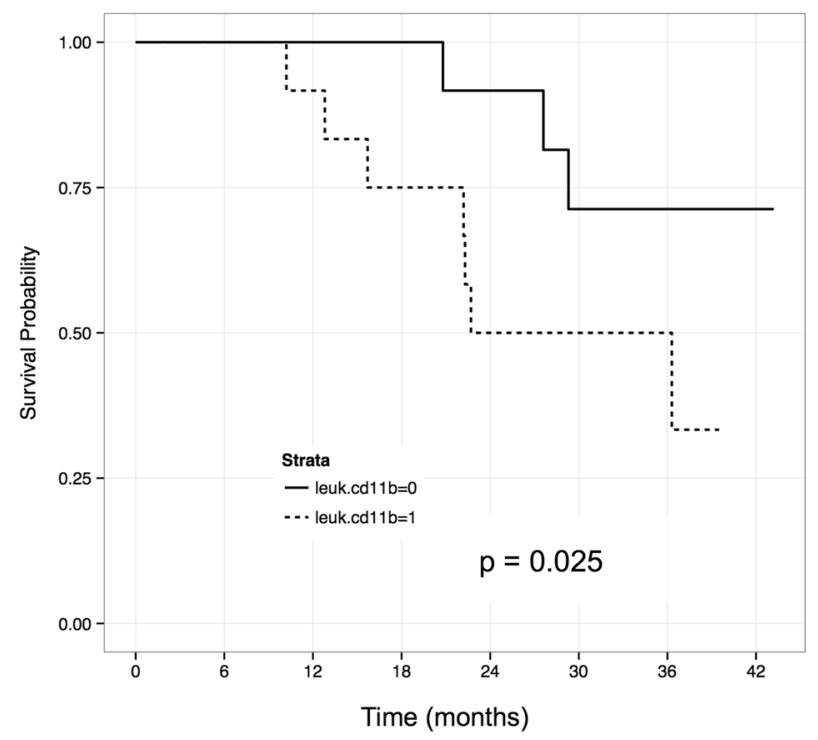

$\begin{array}{lllllllll}\text { leuk.cd11b=0 } & 12 & 12 & 12 & 12 & 10 & 6 & 2 & 1 \\ \text { leuk.cd11b=1 } & 12 & 12 & 11 & 9 & 6 & 5 & 3 & 0\end{array}$

Numbers at risk

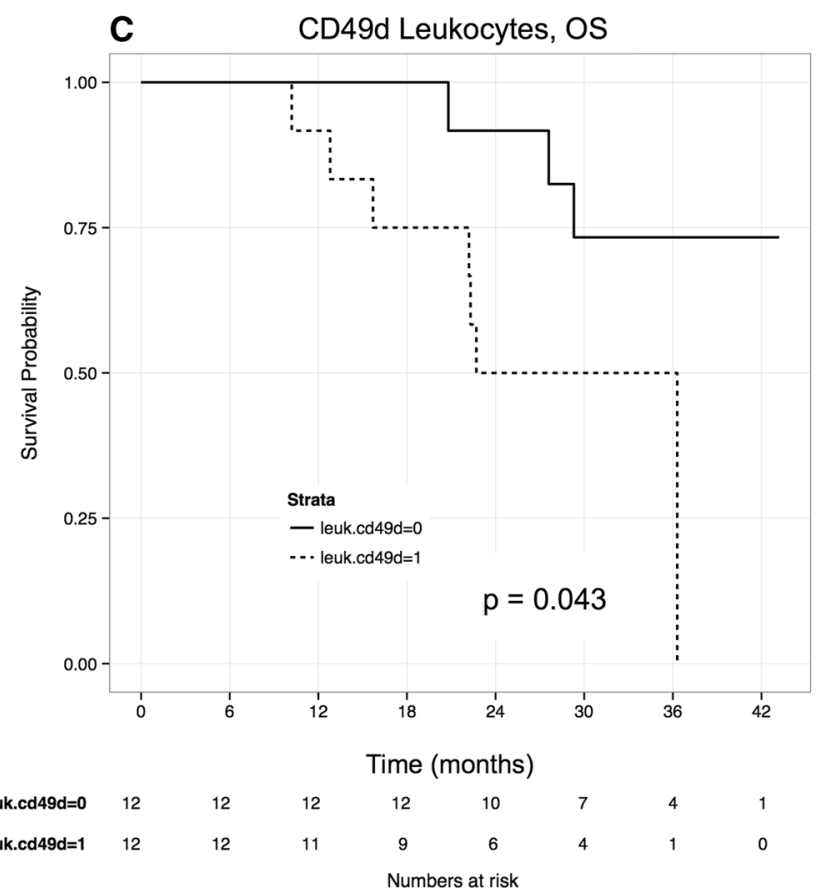

Fig. 3 Univariate cox proportional hazard models were used to evaluate associations between surface antigen levels and overall survival (OS). For graphical representation, plotted variables were dichotomized based on median antigen levels, $0=$ low, $1=$ high.

B-lymphocytes, indicated by elevated CD79b, may be related to lymphangiogenesis, increased lymph flow and subsequent tumor dissemination in stage III metastatic melanoma patients with reduced OS. Interestingly, protective cell-mediated immunity provoked by adenoviral-

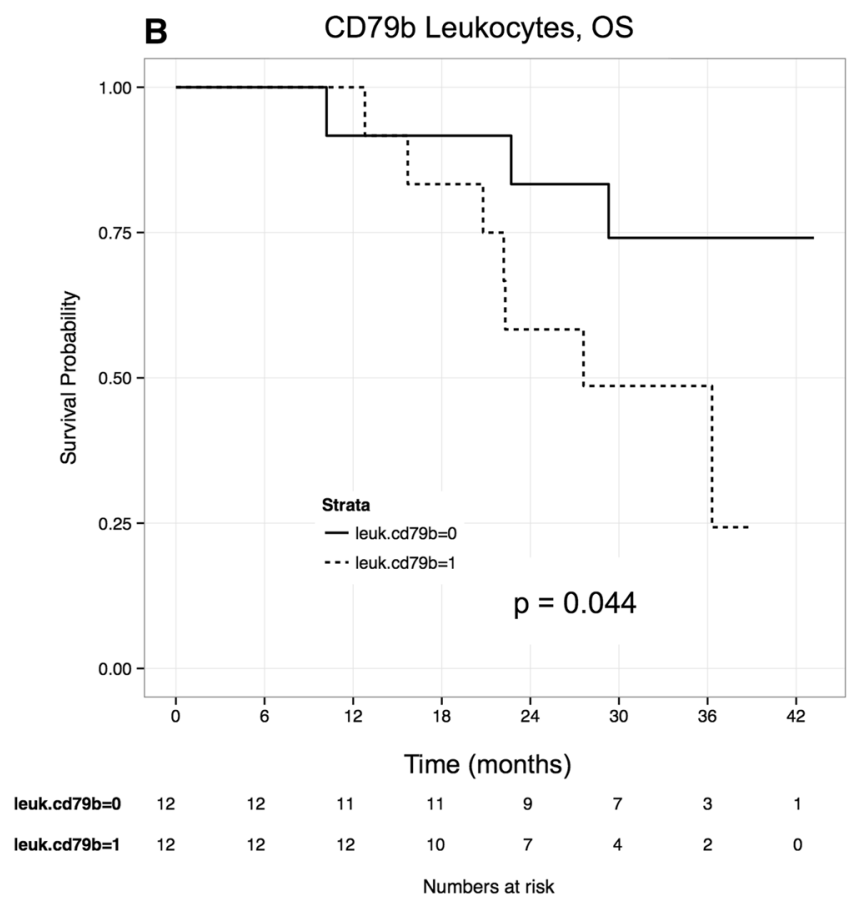

D CD39 Leukocytes, OS

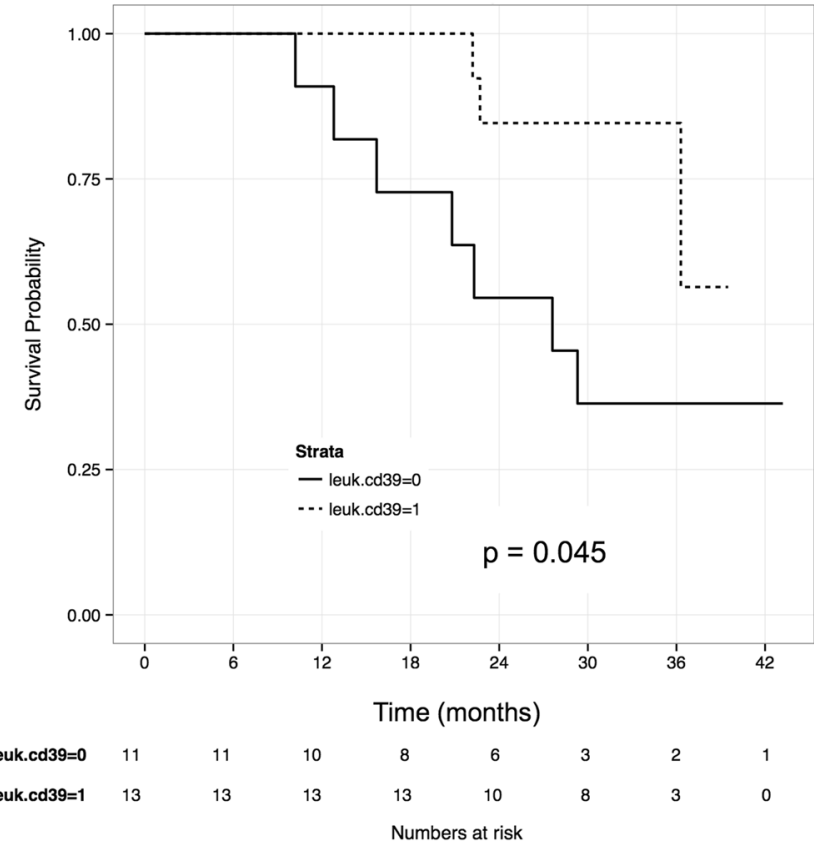

Increased levels of (a) CD11b, (b) CD79b and (c) CD49d on CD45 leukocytes were significantly associated with reduced overall survival, whereas higher levels of (d) CD39 was associated with increased survival

based cancer vaccines is enhanced in the absence of B-cells, suggesting that a therapeutic regimen that includes depletion of B-lymphocytes may be beneficial [40].

We detected higher levels of integrins $\alpha_{M}$ (CD11b) and $\alpha_{4}$ (CD49d) on $\mathrm{CD}^{+} 5^{+}$leukocytes in $\mathrm{LN}$ tumors from 
Table 2 Leukocyte antigens significantly associated with survival

\begin{tabular}{|c|c|c|c|c|c|}
\hline \multirow[t]{2}{*}{ Acc. $\#^{\mathrm{a}}$} & \multirow{2}{*}{$\begin{array}{l}\text { Antigen/protein } \\
\text { name }\end{array}$} & \multicolumn{2}{|c|}{ Univariate } & \multicolumn{2}{|c|}{ Multivariate $^{\mathrm{d}}$} \\
\hline & & $\mathrm{HR}^{\mathrm{b}}$ & $p$ value $^{c}$ & $H R^{\mathrm{b}}$ & $p$ value $^{\mathrm{e}}$ \\
\hline \multicolumn{6}{|c|}{ Distant metastasis-free survival } \\
\hline P12926 & CD9 (tetraspanin-29) & 2.67 & 0.039 & 3.73 & 0.036 \\
\hline P49961 & $\begin{array}{l}\text { CD39 (ecto-ATPase } \\
\text { diphosphohydro- } \\
\text { lase 1) }\end{array}$ & 0.29 & 0.019 & 0.010 & 0.004 \\
\hline P08174 & $\begin{array}{l}\text { CD55 (complement } \\
\text { decay-accelerating } \\
\text { factor) }\end{array}$ & 0.28 & 0.006 & 0.098 & 0.005 \\
\hline \multicolumn{6}{|c|}{ Overall survival } \\
\hline P11215 & CD11b (integrin $\alpha M$ ) & 2.72 & 0.025 & 1.75 & $>0.2$ \\
\hline P49961 & $\begin{array}{l}\text { CD39 (ecto-ATPase } \\
\text { diphosphohydro- } \\
\text { lase 1) }\end{array}$ & 0.29 & 0.045 & 0.099 & 0.016 \\
\hline P13612 & CD49d (integrin $\alpha 4$ ) & 2.46 & 0.043 & 1.22 & $>0.2$ \\
\hline P40259 & $\begin{array}{l}\text { CD79b (B-cell antigen } \\
\text { receptor complex- } \\
\text { associated protein } \beta \\
\text { chain) }\end{array}$ & 1.76 & 0.044 & 1.36 & $>0.2$ \\
\hline
\end{tabular}

$\overline{{ }^{a} \text { Accession numbers were obtained from UniProtKB/Swiss-Prot }}$ knowledgebase (www.uniprot.org)

${ }^{b} H R$ Hazard ratio

${ }^{c}$ Log-rank test, significance level $p<0.05$

${ }^{d}$ Multivariate survival model, including age, gender and AJCC stage at lymph node recurrence

e Wald test, significance level $p<0.05$

patients with reduced OS. CD11b is found primarily on innate immune cells of myeloid lineage, and plays important roles in cell adhesion, migration, chemotaxis, and phagocytosis [41]. Melanoma cell extravasation was decreased following a reduction in integrin $\alpha_{M} \beta_{2}$ levels on polymorphonuclear neutrophils by functional blocking of IL-8 binding [42], implicating CD11b in melanoma metastasis. Myeloid-derived suppressor cells (MDSCs) are over-produced in tumor-bearing hosts, constituting approximately $5 \%$ of total cells in tumors [43]. MDSCs are $\mathrm{CD} 11 \mathrm{~b}^{+} / \mathrm{Gr}-1^{+}$(marker for granulocytes) and contribute significantly to immune escape, intravasation and angiogenesis [44]. These potent immunosuppressors can elicit systemic effects on secondary lymphoid organs as well as local effects within the tumor microenvironment [44] and can compromise the efficacy of cancer immunotherapy $[45,46]$. CD11b ${ }^{+}$MDSCs were enriched in melanomas and lymphatic organs during tumor progression [47]. Recently, two sub-populations of MDSCs were described, based on the expression of CD49d. The CD49d ${ }^{+}$ subset of MDSCs is mainly monocytic and suppresses antigen-specific $\mathrm{T}$ cell proliferation in a nitric oxidedependent mechanism, more potently than $\mathrm{CD}_{11} \mathrm{~b}^{+}$/ $\mathrm{CD} 4 \mathrm{~d}^{-}$MDSCs [48]. The association between reduced
Table 3 Antigens with significant correlation to the disease-free interval

\begin{tabular}{|c|c|c|c|}
\hline Acc. $\#^{\mathrm{a}}$ & Antigen/protein name & $\mathrm{r}^{2 \mathrm{~b}}$ & $p$ value $^{\mathrm{c}}$ \\
\hline \multicolumn{4}{|c|}{ CD45 enriched melanoma cells } \\
\hline P05556 & CD29 (Integrin $\beta 1)$ & 0.494 & 0.0267 \\
\hline P28906 & $\begin{array}{l}\text { CD34 (Hematopoietic progenitor } \\
\text { cell antigen CD34) }\end{array}$ & 0.489 & 0.0295 \\
\hline P28907 & CD38 (ADP-ribosyl cyclase 1) & 0.451 & 0.0460 \\
\hline P17301 & CD49c (Integrin $\alpha 3$ ) & 0.462 & 0.0400 \\
\hline P13591 & $\begin{array}{l}\text { CD56 (Neural cell adhesion } \\
\text { molecule } 1 ; \text { NCAM1) }\end{array}$ & 0.452 & 0.0454 \\
\hline P13987 & $\begin{array}{l}\text { CD59 (Membrane attack complex } \\
\text { inhibition factor) }\end{array}$ & 0.485 & 0.0301 \\
\hline P02786 & $\begin{array}{l}\text { CD71 (Transferrin receptor protein } \\
\text { 1) }\end{array}$ & 0.462 & 0.0400 \\
\hline P04216 & $\begin{array}{l}\text { CD95 (Apoptosis-mediating surface } \\
\text { antigen FAS) }\end{array}$ & 0.593 & 0.0058 \\
\hline P08962 & $\begin{array}{l}\text { CD63 (Tetraspanin-30; Lysosomal- } \\
\text { associated membrane protein 3; } \\
\text { Melanoma-associated antigen } \\
\text { ME491) }\end{array}$ & 0.475 & 0.0344 \\
\hline P11279 & $\begin{array}{l}\text { CD107a (Lysosome associated } \\
\text { membrane protein 1; LAMP-1) }\end{array}$ & 0.489 & 0.0286 \\
\hline P41217 & $\begin{array}{l}\text { CD200 (OX-2 membrane } \\
\text { glycoprotein) }\end{array}$ & 0.472 & 0.0358 \\
\hline \multicolumn{4}{|c|}{$\mathrm{CD} 45^{+}$Leukocytes } \\
\hline \multirow[t]{2}{*}{ P09564 } & CD 7 (T-cell antigen CD7) & -0.542 & 0.0164 \\
\hline & $\begin{array}{l}\text { CD } 8 \text { (T-cell glycoprotein CD8) }-\alpha \\
\text { (Acc. \# P01732) and } \beta \text { (Acc. \# } \\
\text { P10966) chains }\end{array}$ & -0.677 & 0.0014 \\
\hline P16150 & CD 43 (Leukosialin) & -0.481 & 0.0370 \\
\hline P05362 & $\begin{array}{l}\text { CD } 54 \text { (Intercellular adhesion } \\
\text { molecule 1; ICAM1) }\end{array}$ & -0.642 & 0.0030 \\
\hline P13591 & $\begin{array}{l}\text { CD } 56 \text { (Neural cell adhesion } \\
\text { molecule } 1 ; \text { NCAM1) }\end{array}$ & -0.522 & 0.0219 \\
\hline P11911 & $\begin{array}{l}\text { CD 79a (Surface IgM-associated } \\
\text { protein) }\end{array}$ & -0.523 & 0.0217 \\
\hline P38570 & CD 103 (Integrin E) & -0.550 & 0.0146 \\
\hline P43489 & $\begin{array}{l}\text { CD } 134 \text { (Tumor necrosis factor } \\
\text { receptor superfamily member } 4 \text { ) }\end{array}$ & -0.614 & 0.0052 \\
\hline Q13740 & $\begin{array}{l}\text { CD } 166 \text { (Activated leucocyte cell } \\
\text { adhesion molecule) }\end{array}$ & -0.758 & 0.0002 \\
\hline
\end{tabular}

\footnotetext{
a Accession numbers were obtained from UniProtKB/Swiss-Prot knowledgebase (www.uniprot.org)

${ }^{b}$ Pearson product momentum coefficient, $r^{2} \cdot r^{2}>0$ is indicative of a positive relationship between antigen expression levels and a long disease-free interval, whereas $r^{2}<0$ describes decreased antigen levels associated with a short disease-free interval

${ }^{c}$ Unadjusted $p$ values, significance level $p<0.05$
}

OS and increased levels of CD11 $\mathrm{b}^{+}$and CD49d $\mathrm{d}^{+}$on leukocytes from LNs containing metastatic melanoma may be attributed to MDSCs capable of potentiating local immunosuppression. 
Fig. 4 Western blot verifying increased CD55 on CD45 ${ }^{+}$ leukocytes fractionated from Stage III metastatic melanoma patients with distant metastasisfree survival $(\mathrm{HR}=2.8$; $p=0.008)$. Succinate dehydrogenase subunit A (SDHA) and total protein stains were used as loading controls

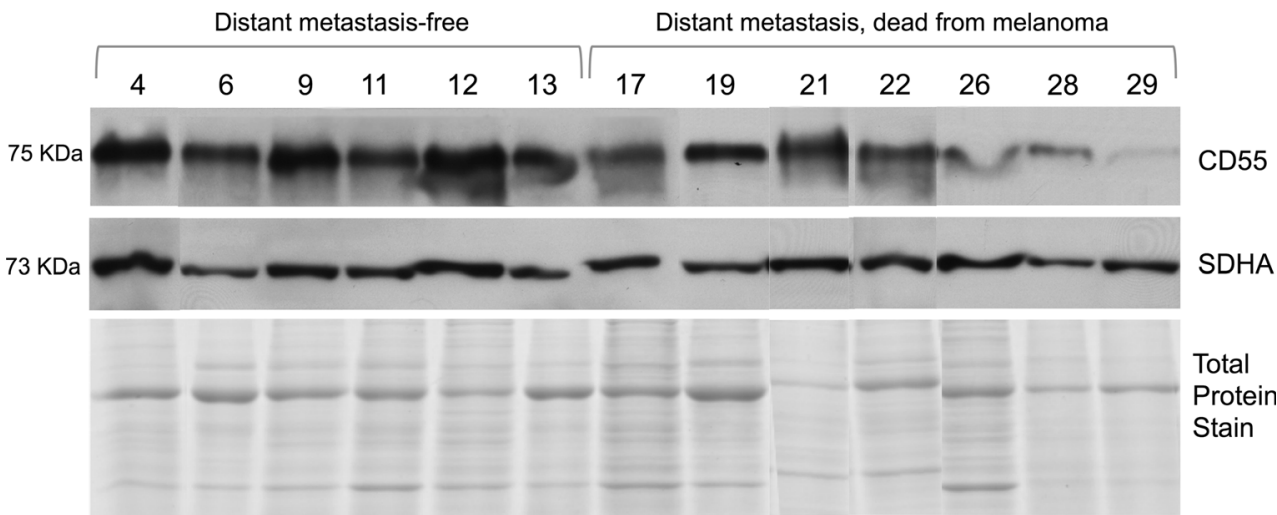

Levels of CD9 were increased on $\mathrm{CD} 45^{+}$leukocytes isolated from LNs resected from melanoma patients with reduced DMFS. CD9 is a tetraspanin, expressed on immune cells of lymphoid and myeloid lineages. By treating peripheral natural killer $(\mathrm{NK})$ cells with transforming growth factor (TGF)- $\beta 1$ under hypoxic culture conditions, Cedeira et al. generated a population of $\mathrm{CD} 9^{+}$ $\mathrm{NK}$ cells that secreted pro-angiogenic factors and have reduced cytotoxicity [49]. TGF- $\beta 1$ serum levels positively correlate with melanoma stage and higher levels are prognostic for reduced OS [50]. NK cells that express CD9 were thought to only occur in the female reproductive system, however a CD9 ${ }^{+} \mathrm{NK}$ cell population was recently detected in the peripheral blood of metastatic melanoma patients [51]. Altered NK cell function is a component of global immune dysregulation that occurs in advanced malignancies and a number of NK cell-based immunotherapies of melanoma are under investigation. Further analysis of the role of $\mathrm{CD}^{+}$leukocytes in progression of metastatic melanoma is warranted.

\section{Leukocyte antigens associated with increased survival}

Higher CD55 (decay-accelerating factor) levels on leukocytes were associated with longer DMFS on univariate and multivariate analyses $(p=0.006$ and 0.005), a finding confirmed by Western blot analysis (Fig. 4; $p=0.008$ ). CD55 is a ubiquitous complement regulatory protein that is critical for protection from bystander complement-mediated attack. Enhanced levels of CD55 may simply protect leukocytes from complement-mediated lysis. Interestingly, in our recent comprehensive proteomic analyses of lymph nodes resected from stage IIIc melanoma patients, several complement proteins (complement $\mathrm{C} 3$, clustin and complement component 1Q sub-component-binding protein) were differentially abundant between patients with good $(>4$ years survival) and poor $(<1$ year survival) prognoses $(n=33)$. Moreover, the top ranking (FDR $<0.01)$ pathway maps generated by MetaCore ${ }^{\mathrm{TM}}\left(\mathrm{GeneGO}^{\mathrm{TM}}\right.$, Encinitas, CA, USA) involved complement pathways (S. Mactier et al. unpublished data, 2013). CD55 also co-stimulates T-cells when engaged and cross-linked by antibodies [52, 53]. CD55 is also a ligand for CD97 and may be required to stabilize T-cell receptor-MHC engagement to enhance T-cell function [54]. Although this finding was confirmed using Western blot $(n=13 ; 2$ patients independent of microarray analysis), investigation of CD55 antigen levels on leukocytes in a larger patient cohort is required.

High levels of CD39 (Ecto ATP-diphosphohydrolase 1) on $\mathrm{CD} 45^{+}$leukocytes were associated with increased OS and DMFS. CD39 is expressed by a broad range of immune cells and catalyzes the sequential hydrolysis of ATP to AMP that is further degraded to anti-inflammatory adenosine. In the immune system, extracellular ATP functions as a "natural adjuvant" that exhibits multiple pro-inflammatory effects and is known to boost immune responses in the tumor microenvironment. Deletion of CD39 in a murine model abrogated angiogenesis, leading to reduced growth and metastasis of subcutaneous melanoma tumors [55]. However, our results show that the presence of higher CD39 on $\mathrm{CD} 45^{+}$leukocytes confers a survival advantage. In the context of $\mathrm{LN}$ metastases, reduced CD39 levels would allow extracellular ATP to trigger a more pronounced inflammatory response [56] that can induce lymphangiogenesis and promote tumor cell dissemination [36]. Therefore, opposed to the documented immunosuppressive properties, higher CD39 levels in patients with longer DMFS and OS may reflect reduced lymphatic dissemination of metastatic melanoma. As CD73 works in concert with CD39 to catalyze the conversion of AMP to adenosine [57], we examined levels of CD73 in our dataset. Increased CD73 on CD45 ${ }^{+}$ leukocytes were associated with DMFS with marginal significance. Although CD39 and CD73 require further investigation in a larger patient cohort, we have observed 
a trend of increased co-expression levels on $\mathrm{CD} 45^{+}$leukocytes from patients with longer DMFS.

\section{CD117 is associated with distant metastasis and poor survival on enriched melanoma cells}

Increased levels of the receptor tyrosine kinase CD117 (cKIT) on enriched melanoma cells $\left(\mathrm{CD} 45^{-}\right)$were associated with distant metastasis and poor survival outcomes but this was not statistically significant $(p=0.07)$. The reversible expression of surface antigens on melanoma cells [58] as well as the presence of other non-hematopoietic cell types could explain the limited stratification of the $\mathrm{CD} 45^{-}$cell population obtained in our study.

Surface antigens associated with a prolonged disease free interval

The time interval between removal of the primary melanoma and detection of metastatic disease is very variable and can span many years, or even decades. The mechanisms by which metastatic disease may be present but remain clinically undetected for such prolonged periods, presumably influenced by interactions between the melanoma phenotype and the patient's immune system, have not received sufficient attention to date [59]. A better understanding of the molecular cross-talk between tumor cells, immune cells and the extracellular matrix in secondary sites, and how these regulate metastatic disease progression, may lead to improved therapeutic strategies to eradicate them or at least to induce or maintain disseminated tumor cells in a clinically-silent chronic disease ("dormant") state [60]. Adjuvant therapies, such as antibodies that target metastatic melanoma cells are of considerable interest [61, 62]. We performed correlation analyses of antigen levels and the DFI (time from primary diagnosis and detection of LN metastasis) to identify surface antigen signatures associated with melanoma progression following prolonged disease-free (latent) intervals.

\section{Cell adhesion markers on enriched melanoma cells $\left(C D 45^{-}\right)$correlate with longer disease-free intervals}

The tumor microenvironment is a critical regulator of cancer progression [60] and integrin-mediated interactions between tumor cells and the extracellular matrix (ECM) modulate the metastatic potential of tumor cells [63]. We identified higher levels of the integrins CD29 and CD49c on $\mathrm{CD} 45^{-}$cells from metastatic $\mathrm{LN}$ tumors following a prolonged DFI. Integrins are trans-membrane proteins involved in cell adhesion, migration, proliferation and signal transduction [64]. To escape a dormant state, tumor cells must engage with the ECM via integrin receptor(s), inducing signalling that leads to cytoskeletal reorganisation and cell proliferation [60]. Integrin-containing complexes interact with the ECM via actin filaments and focal adhesion complexes, but also regulate, and are regulated by receptor tyrosine kinases and other signalling pathways $[65,66]$. There is growing evidence implicating CD29 (integrin $\beta 1$ ) heterodimers and signal transducers in regulating tumor cell dormancy [63, 67-69]. Other antigens involved in cell adhesion were increased on $\mathrm{CD} 45^{-}$cells following reactivated dormant disease, including CD56, CD63 and CD107a.

\section{Reduced levels of T-cell activation markers in $L N$ metastases resected after a prolonged disease-free interval}

Metastatic melanoma is highly immunogenic, however attempts to boost patient immunity and/or vaccinate against melanoma have had limited success [70, 71]. Melanoma cells are capable of immune subversion within a tumor or draining LN by altering dendritic cell function through the secretion of tumor-derived cytokines [72], leading to the generation of suppressive and regulatory T-cells [73]. T-cell-mediated immunity is an important component in the regulation of tumor dormancy [74]. In transgenic mouse models, $\mathrm{CD} 8^{+} \mathrm{T}$-cells appear to halt the expansion of disseminated melanoma cells in the bone marrow and LNs [75]. Moreover, $\mathrm{CD} 8^{+} \mathrm{T}$-cells appear to have distinct roles in controlling disease progression and metastatic spread [76], suggesting that the effect of immune cells on melanoma dormancy might depend on the microenvironment [59]. Here we found a significant correlation between reduced CD8 T-cells in patients with stage III metastatic disease resected following a long DFI. Interestingly, 7 other antigens involved in T-cell immunity were reduced in these patients, including CD7, CD43, CD54 [77], CD56 [78], CD103 [79], CD134 [17] and CD166 [80]. Decreased CD134 levels on $\mathrm{CD}^{+}{ }^{+}$T-cells in sentinel LNs draining primary melanomas correlated with more advanced tumor features and nodal involvement [17]. Overall, these results suggest that a local immuno-suppressive LN microenvironment may induce the reactivation and expansion of dormant tumor cells.

\section{Conclusions}

Surface markers prognostic for survival identified here require validation in a larger, independent cohort of stage III melanoma patients. The significant findings of low CD9 (DMFS) and high CD55 (DMFS) and CD39 (DMFS and OS) levels on $\mathrm{CD} 45^{+}$leukocytes with better survival outcomes on multivariate analysis warrants further study. 
Enhanced expression of the adhesion markers CD29, CD49c, CD56, CD63 and CD107a on CD45 melanoma cells and loss of T-cell-related immunity is implicated in melanoma progression following a prolonged period in which metastatic disease has remained clinically silent/ undetected. A better understanding of the interplay of melanoma cells, the immune system and the factors that control them will enable more accurate prognostication and furthermore, provide new therapeutic approaches to treat this complex, heterogeneous cancer.

Acknowledgments We thank Candace Carter, James Wilmot, Kenneth Lai, Chitra De Silva, Rajmohan Murali and other staff of the Melanoma Institute Australia and Department of Tissue Pathology and Diagnostic Oncology, Royal Prince Alfred Hospital for their assistance in collection of fresh surgical samples. The assistance of staff of the MIA in procuring the surgical melanoma specimens and other clinical data is gratefully acknowledged. A Cancer Institute NSW Translational Program grant awarded to the MIA (G.J.M., J.F.T., R.A.S. and R.I.C.) funded this work. This work was also supported by an NHMRC program grant (to J.F.T., G.J.M. and R.A.S.). K.L.K. is supported by an NHMRC Australian Biomedical Fellowship. S.N.B. was supported by a Cancer Institute NSW Career Development and Support Fellowship (07/CDF/01-07). R.A.S. is supported by the Cancer Institute NSW and NHMRC Fellowship programs. A special thank you to the Cracknell family for their kind bequest to K.L.K made in honour of Terry's courageous battle with metastatic melanoma. R.I.C. holds US and European patents for DotScan $^{\mathrm{TM}}$ microarrays used in the present study and has $<2 \%$ equity in Medsaic Pty. Ltd.

Open Access This article is distributed under the terms of the Creative Commons Attribution License which permits any use, distribution, and reproduction in any medium, provided the original author(s) and the source are credited.

\section{References}

1. Thompson JF, Scolyer RA, Kefford RF (2005) Cutaneous melanoma. Lancet 365(9460):687-701

2. Godar DE (2011) Worldwide increasing incidences of cutaneous malignant melanoma. J Skin Cancer 2011:858425

3. Reed KB et al (2012) Increasing incidence of melanoma among young adults: an epidemiological study in Olmsted County, Minnesota. Mayo Clin Proc 87(4):328-334

4. Bedrosian I et al (2000) Incidence of sentinel node metastasis in patients with thin primary melanoma $(<$ or $=1 \mathrm{~mm})$ with vertical growth phase. Ann Surg Oncol 7(4):262-267

5. Balch CM et al (2001) Prognostic factors analysis of 17,600 melanoma patients: validation of the American Joint Committee on Cancer melanoma staging system. J Clin Oncol 19(16):3622-3634

6. Gould Rothberg BE, Bracken MB, Rimm DL (2009) Tissue biomarkers for prognosis in cutaneous melanoma: a systematic review and meta-analysis. J Natl Cancer Inst 101(7):452-474

7. Gould Rothberg BE, Rimm DL (2010) Biomarkers: the useful and the not so useful-an assessment of molecular prognostic markers for cutaneous melanoma. J Invest Dermatol 130(8):1971-1987

8. Bilalovic $\mathrm{N}$ et al (2004) CD10 protein expression in tumor and stromal cells of malignant melanoma is associated with tumor progression. Mod Pathol 17(10):1251-1258
9. Cruz J et al (2003) Expression of c-met tyrosine kinase receptor is biologically and prognostically relevant for primary cutaneous malignant melanomas. Oncology 65(1):72-82

10. Dietrich A et al (1997) High CD44 surface expression on primary tumours of malignant melanoma correlates with increased metastatic risk and reduced survival. Eur J Cancer 33(6):926-930

11. Fogel $\mathrm{M}$ et al (2003) L1 adhesion molecule (CD 171) in development and progression of human malignant melanoma. Cancer Lett 189(2):237-247

12. Fujii $\mathrm{H}$ et al (1995) Human melanoma invasion and metastasis enhancement by high expression of aminopeptidase N/CD13. Clin Exp Metastasis 13(5):337-344

13. Kanekura T, Chen X, Kanzaki T (2002) Basigin (CD147) is expressed on melanoma cells and induces tumor cell invasion by stimulating production of matrix metalloproteinases by fibroblasts. Int J Cancer 99(4):520-528

14. Kanitakis J, Narvaez D, Claudy A (2002) Differential expression of the CD10 antigen (neutral endopeptidase) in primary versus metastatic malignant melanomas of the skin. Melanoma Res 12(3):241-244

15. Meier F et al (2006) The adhesion molecule L1 (CD171) promotes melanoma progression. Int J Cancer 119(3):549-555

16. Reschke M et al (2008) HER3 is a determinant for poor prognosis in melanoma. Clin Cancer Res 14(16):5188-5197

17. Sarff M et al (2008) OX40 (CD134) expression in sentinel lymph nodes correlates with prognostic features of primary melanomas. Am J Surg 195(5):621-625 discussion 625

18. Scala S et al (2005) Expression of CXCR4 predicts poor prognosis in patients with malignant melanoma. Clin Cancer Res 11(5): 1835-1841

19. van den Oord JJ et al (1996) CD40 is a prognostic marker in primary cutaneous malignant melanoma. Am J Pathol 149(6):1953-1961

20. Wang $\mathrm{H}$ et al (2012) NT5E (CD73) is epigenetically regulated in malignant melanoma and associated with metastatic site specificity. Br J Cancer 106(8):1446-1452

21. Belov L et al (2001) Immunophenotyping of leukemias using a cluster of differentiation antibody microarray. Cancer Res 61(11):4483-4489

22. Belov L et al (2006) Analysis of human leukaemias and lymphomas using extensive immunophenotypes from an antibody microarray. Br J Haematol 135(2):184-197

23. Belov L et al (2003) Identification of repertoires of surface antigens on leukemias using an antibody microarray. Proteomics 3(11):2147-2154

24. Barber $\mathrm{N}$ et al (2009) Profiling CD antigens on leukaemias with an antibody microarray. FEBS Lett 583(11):1785-1791

25. Kaufman KL et al (2010) An extended antibody microarray for surface profiling metastatic melanoma. J Immunol Methods $358(1-2): 23-34$

26. Lal S et al (2004) Increases in leukocyte cluster of differentiation antigen expression during cardiopulmonary bypass in patients undergoing heart transplantation. Proteomics 4(7):1918-1926

27. White SL et al (2005) Immunophenotypic changes induced on human HL60 leukaemia cells by 1alpha,25-dihydroxyvitamin D3 and 12-Otetradecanoyl phorbol-13-acetate. Leuk Res 29(10):1141-1151

28. Woolfson A et al (2005) Conservation of unique cell-surface CD antigen mosaics in HIV-1-infected individuals. Blood 106(3): 1003-1007

29. Wu JQ et al (2007) Antibody microarray analysis of cell surface antigens on $\mathrm{CD}^{+}$and $\mathrm{CD} 8^{+} \mathrm{T}$ cells from HIV+ individuals correlates with disease stages. Retrovirology 4:83

30. Mann GJ et al (2013) BRAF mutation, NRAS mutation, and the absence of an immune-related expressed gene profile predict poor outcome in patients with stage III melanoma. J Invest Dermatol 133(2):509-517

31. Murali R et al (2012) Number of primary melanomas is an independent predictor of survival in patients with metastatic melanoma. Cancer 118(18):4519-4529 
32. Pepper MS (2001) Lymphangiogenesis and tumor metastasis: myth or reality? Clin Cancer Res 7(3):462-468

33. Pasquali $\mathrm{S}$ et al (2013) Lymphatic biomarkers in primary melanomas as predictors of regional lymph node metastasis and patient outcomes. Pigment Cell Melanoma Res 26(3):326-337

34. Shayan R et al (2012) Lymphatic vessel density in primary melanomas predicts sentinel lymph node status and risk of metastasis. Histopathology 61(4):702-710

35. Harrell MI, Iritani BM, Ruddell A (2007) Tumor-induced sentinel lymph node lymphangiogenesis and increased lymph flow precede melanoma metastasis. Am J Pathol 170(2):774-786

36. Ruddell A et al (2011) B lymphocytes promote lymphogenous metastasis of lymphoma and melanoma. Neoplasia 13(8):748757

37. Ruddell A et al (2008) p19/Arf and p53 suppress sentinel lymph node lymphangiogenesis and carcinoma metastasis. Oncogene 27(22):3145-3155

38. Grotz TE et al (2012) Regional lymphatic immunity in melanoma. Melanoma Res 22(1):9-18

39. Dadras SS et al (2005) Tumor lymphangiogenesis predicts melanoma metastasis to sentinel lymph nodes. Mod Pathol 18(9):1232-1242

40. Perricone MA et al (2004) Enhanced efficacy of melanoma vaccines in the absence of B lymphocytes. J Immunother 27(4):273281

41. Liu L et al (2011) The calcineurin B subunit $(\mathrm{CnB})$ is a new ligand of integrin alphaM that mediates $\mathrm{CnB}$-induced Apo2L/ TRAIL expression in macrophages. J Immunol 188(1):238-247

42. Dong C, Robertson GP (2009) Immunoediting of leukocyte functions within the tumor microenvironment promotes cancer metastasis development. Biorheology 46(4):265-279

43. Yang L et al (2004) Expansion of myeloid immune suppressor $\mathrm{Gr}^{+} \mathrm{CD} 11 \mathrm{~b}^{+}$cells in tumor-bearing host directly promotes tumor angiogenesis. Cancer Cell 6(4):409-421

44. Yang L, Edwards CM, Mundy GR (2010) Gr- $1^{+} \mathrm{CD} 11 \mathrm{~b}^{+}$myeloid-derived suppressor cells: formidable partners in tumor metastasis. J Bone Miner Res 25(8):1701-1706

45. Serafini P, Borrello I, Bronte V (2006) Myeloid suppressor cells in cancer: recruitment, phenotype, properties, and mechanisms of immune suppression. Semin Cancer Biol 16(1):53-65

46. Marx J (2008) Cancer immunology. Cancer's bulwark against immune attack: MDS cells. Science 319(5860):154-156

47. Meyer C et al (2011) Chronic inflammation promotes myeloidderived suppressor cell activation blocking antitumor immunity in transgenic mouse melanoma model. Proc Natl Acad Sci USA 108(41):17111-17116

48. Haile LA et al (2010) CD49d is a new marker for distinct myeloid-derived suppressor cell subpopulations in mice. J Immunol 185(1):203-210

49. Cerdeira AS et al (2013) Conversion of peripheral blood NK cells to a decidual NK-like phenotype by a cocktail of defined factors. J Immunol 190(8):3939-3948

50. Tas F et al (2006) Circulating serum levels of angiogenic factors and vascular endothelial growth factor receptors 1 and 2 in melanoma patients. Melanoma Res 16(5):405-411

51. Holtan SG et al (2011) Expansion of CD16-negative natural killer cells in the peripheral blood of patients with metastatic melanoma. Clin Dev Immunol 2011:316314

52. Shenoy-Scaria AM et al (1992) Signal transduction through decay-accelerating factor. Interaction of glycosyl-phosphatidylinositol anchor and protein tyrosine kinases p56lck and p59fyn 1 . J Immunol 149(11):3535-3541

53. Davis LS et al (1988) Decay-accelerating factor functions as a signal transducing molecule for human $\mathrm{T}$ cells. J Immunol 141(7):2246-2252
54. Abbott RJ et al (2007) Structural and functional characterization of a novel T cell receptor co-regulatory protein complex, CD97CD55. J Biol Chem 282(30):22023-22032

55. Jackson SW et al (2007) Disordered purinergic signaling inhibits pathological angiogenesis in cd39/Entpd1-null mice. Am J Pathol 171(4):1395-1404

56. Salcido-Ochoa F et al (2010) Regulatory T cells in transplantation: does extracellular adenosine triphosphate metabolism through CD39 play a crucial role? Transplant Rev (Orlando) 24(2):52-66

57. Deaglio S et al (2007) Adenosine generation catalyzed by CD39 and CD73 expressed on regulatory $\mathrm{T}$ cells mediates immune suppression. J Exp Med 204(6):1257-1265

58. Quintana E et al (2010) Phenotypic heterogeneity among tumorigenic melanoma cells from patients that is reversible and not hierarchically organized. Cancer Cell 18(5):510-523

59. Ossowski L, Aguirre-Ghiso JA (2010) Dormancy of metastatic melanoma. Pigment Cell Melanoma Res 23(1):41-56

60. Barkan D, Green JE, Chambers AF (2010) Extracellular matrix: a gatekeeper in the transition from dormancy to metastatic growth. Eur J Cancer 46(7):1181-1188

61. Pantel K, Cote RJ, Fodstad O (1999) Detection and clinical importance of micrometastatic disease. J Natl Cancer Inst 91(13):1113-1124

62. Gorter A, Meri S (1999) Immune evasion of tumor cells using membrane-bound complement regulatory proteins. Immunol Today 20(12):576-582

63. White DE, Rayment JH, Muller WJ (2006) Addressing the role of cell adhesion in tumor cell dormancy. Cell Cycle 5(16): 1756-1759

64. Rallis C, Pinchin SM, Ish-Horowicz D (2010) Cell-autonomous integrin control of Wnt and Notch signalling during somitogenesis. Development 137(21):3591-3601

65. Hannigan G, Troussard AA, Dedhar S (2005) Integrin-linked kinase: a cancer therapeutic target unique among its ILK. Nat Rev Cancer 5(1):51-63

66. Legate KR et al (2006) ILK, PINCH and parvin: the tIPP of integrin signalling. Nat Rev Mol Cell Biol 7(1):20-31

67. Aguirre-Ghiso JA (2007) Models, mechanisms and clinical evidence for cancer dormancy. Nat Rev Cancer 7(11):834-846

68. Aguirre Ghiso JA, Kovalski K, Ossowski L (1999) Tumor dormancy induced by downregulation of urokinase receptor in human carcinoma involves integrin and MAPK signaling. J Cell Biol 147(1):89-104

69. Wang $\mathrm{H}$ et al (2004) Tumor cell $\alpha 3 \beta 1$ integrin and vascular laminin-5 mediate pulmonary arrest and metastasis. J Cell Biol 164(6):935-941

70. Ralph SJ (2007) An update on malignant melanoma vaccine research: insights into mechanisms for improving the design and potency of melanoma therapeutic vaccines. Am J Clin Dermatol 8(3):123-141

71. Terando AM, Faries MB, Morton DL (2007) Vaccine therapy for melanoma: current status and future directions. Vaccine 25(Suppl 2):B4-B16

72. Lee JH et al (2005) Quantitative analysis of melanoma-induced cytokine-mediated immunosuppression in melanoma sentinel nodes. Clin Cancer Res 11(1):107-112

73. Polak ME et al (2009) Melanoma vaccines: the problems of local immunosuppression. Hum Immunol 70(5):331-339

74. Farrar JD et al (1999) Cancer dormancy. VII. A regulatory role for $\mathrm{CD}^{+} \mathrm{T}$ cells and IFN-gamma in establishing and maintaining the tumor-dormant state. J Immunol 162(5):2842-2849

75. Umansky V et al (2008) Melanoma-specific memory T cells are functionally active in Ret transgenic mice without macroscopic tumors. Cancer Res 68(22):9451-9458 
76. Lengagne $\mathrm{R}$ et al (2008) Distinct role for CD8 T cells toward cutaneous tumors and visceral metastases. $\mathrm{J}$ Immunol 180(1):130-137

77. Kuhlman P et al (1991) The accessory function of murine intercellular adhesion molecule-1 in $\mathrm{T}$ lymphocyte activation. Contributions of adhesion and co-activation. $\mathrm{J}$ Immunol 146(6):1773-1782

78. Kelly-Rogers $\mathbf{J}$ et al (2006) Activation-induced expression of CD56 by $\mathrm{T}$ cells is associated with a reprogramming of cytolytic activity and cytokine secretion profile in vitro. Hum Immunol 67(11):863-873

79. Anz D et al (2011) CD103 is a hallmark of tumor-infiltrating regulatory T cells. Int J Cancer 129(10):2417-2426

80. Ofori-Acquah SF, King JA (2008) Activated leukocyte cell adhesion molecule: a new paradox in cancer. Transl Res 151(3):122-128 